\title{
Synergistic effects of IL-4 and TNFa on the induction of B7-H1 in renal cell carcinoma cells inhibiting allogeneic $\mathrm{T}$ cell proliferation
}

\author{
Dagmar Quandt, Simon Jasinski-Bergner, Ulrike Müller, Bianca Schulze and Barbara Seliger*
}

\begin{abstract}
Background: The importance of B7-H molecules for the T cell/tumor communication and its impact on renal cell carcinoma (RCC) progression and prognosis has been recently described. Cytokine treatment of RCC has earlier been shown to be beneficial in preclinical settings, but its clinical implementation has not proven to be as effective. This might be partially explained by the yet incomplete picture of cellular alterations in tumor cells upon cytokine treatment investigated in detail in this study.

Methods: RCC tumor cell lines were treated with different cytokines alone or in combination. The constitutive and/or cytokine-induced expression of cytokine receptors signaling components and B7-H molecules in RCC cells were analysed by qPCR and flow cytometry. A mcherry reporter gene construct containing B7-H1 promoter was cloned and its activity was determined upon transfection in cytokine-stimulated cells. Cytokine pretreated tumor cells were co-cultured with allogeneic $\mathrm{CD}^{+} \mathrm{T}$ cells from healthy donors and $\mathrm{T}$ cell proliferation as well as cytokine secretion was determined.

Results: A heterogeneous, but constitutive $\mathrm{B} 7-\mathrm{H} 1,-\mathrm{H} 2,-\mathrm{H} 3$ and $\mathrm{H} 4$ expression was found on human RCC cell lines. IL-4 and TNFa treatment led to strong synergistic induction of $\mathrm{B} 7-\mathrm{H} 1$ in $\mathrm{RCC}$ cells, whereas $\mathrm{B} 7-\mathrm{H} 2$ was only increased by TNFa. In contrast, B7-H3 and B7-H4 expression were not altered by these cytokines. Treatment of RCC cells with TNFa and IL-4 was accompanied by an activation of signaling molecules like NF-KB, IKB and STAT6. The cytokine-mediated up-regulation of $\mathrm{B} 7-\mathrm{H} 1$ was due to transcriptional control as determined by an increased $\mathrm{B} 7-\mathrm{H} 1$ promoter activity in the presence of IL-4 and TNFa. Despite HLA class I and LFA-1 were also increased, the cytokine-mediated up-regulation of $\mathrm{B} 7-\mathrm{H} 1$ was more pronounced and caused an inhibition of allospecifc $\mathrm{CD} 8^{+} \mathrm{T}$ cell proliferation.
\end{abstract}

Conclusion: Thus, IL-4 and TNFa, which could be released by immune cells of the tumor microenvironment, are able to control the B7-H1 expression in RCC thereby altering T cell responses. These data are of importance for understanding the complex interplay of tumor cells with immune cells orchestrated by a number of different soluble and membrane bound mediators and for the implementation of check point antibodies directed against B7-H1.

Keywords: Renal cell carcinoma, Costimulation, T cells, Anti-tumor response, B7-H molecules

\section{Background}

Renal cell carcinoma (RCC) is the most common kidney cancer type with an incidence of 5.8 in 100.000 people in the Western world [1] causing death of 5327 patients/ year in Germany [2]. These results document the need for ongoing research to identify novel therapeutic strategies and to investigate mechanisms of tumor immune escape. RCC is considered an immunogenic tumor as

\footnotetext{
* Correspondence: barbara.seliger@uk-halle.de

Institute of Medical Immunology, Martin Luther University Halle-Wittenberg, Magdeburger Str. 2, Halle 06112, Germany
}

demonstrated by a high frequency of tumor-infiltrating immune cells, a relatively high incidence of spontaneous recurrences as well as by the efficacy of immunotherapies, like DC-based vaccines, engineered autologous tumor cells, targeting $\mathrm{T}$ cell-tumor interaction, stem cell transplantation and treatment with cytokines [3].

B7 molecules are a growing protein family with diverse functions on both immune and tumor cells. They play in particular a key role in the crosstalk of the immune system and cancer tissues in different tumor entities [4]. B7 family members are mainly described to modulate $\mathrm{T}$ cell 
responses as second signal in cooperation with the first signal, the antigen recognition mediated by binding of the $\mathrm{T}$ cell receptor (TCR) with the major histocompatibility complex (MHC). These signals can be of co-inhibitory or co-stimulatory nature. Interestingly, also a reverse signaling in $\mathrm{B} 7$ family member expressing cells has been discovered [5]. The B7 family comprises B7-1 (CD80), B7-2 (CD86), B7-H1 (PD-L1), B7-DC (PD-L2), B7-H2 (ICOS-L), B7-H3, B7-H4 and B7-H6 [6,7]. Many tumors of distinct origin express B7-H molecules, in particular B7-H1. Therefore, monoclonal antibodies (mAb) targeting PDL1/B7-H1 on tumor cells or the PD1 receptor expressed by immune cells have been developed for the treatment of tumors. These antibodies are currently implemented in clinical trials demonstrating promising objective response rates in various tumors [8].

In the context of RCC B7-H1 expression of tumor lesions is associated with a worse prognosis of RCC patients [9]. The prognostic relevance of $\mathrm{B} 7-\mathrm{H} 1$ in $\mathrm{RCC}$ was further strengthened by the fact that $\mathrm{B} 7-\mathrm{H} 1 \mathrm{mRNA}$ is increased in early metastasis when compared to primary lesions suggesting that $\mathrm{B} 7-\mathrm{H} 1$ might serve as marker of a metastatic signature in RCC [10].

Cytokines are a family of modulatory proteins or glycoproteins that bind to their respective receptors on a variety of different immune and cancer cells thereby inducing different downstream signaling processes. Studies of cytokines are complicated due to their pleiotropy and apparent redundancies of action [11].

Over two decades one conventional treatment regime for patients with RCC included cytokines like IFN- $\alpha$ and IL-2. Despite the results were promising in preclinical settings [12-14], the clinical efficacy was rather poor with antitumoral responses ranging between $10-20 \%$ [15-18]. This might be due to the lack of knowledge of the tumor microenvironment, the molecular alterations and heterogeneity of tumors including those concerning the B7 family members in tumor and immune cells upon cytokine treatment.

With the exception of interferon (IFN)- $\gamma[19,20]$ the effect of different cytokines on the regulation of $\mathrm{B} 7-\mathrm{H}$ molecules on RCC cells is widely unknown. Therefore, this study analyzed the regulation of $\mathrm{B} 7-\mathrm{H}$ molecules upon cytokine treatment in RCC in detail. B7-H1 surface expression was most dramatically altered upon IL-4 and TNF $\alpha$. This enhancement occurred at the transcriptional level by direct upregulation of the $\mathrm{B} 7-\mathrm{H} 1$ promoter activity, which was associated with an inhibition of $\mathrm{T}$ cell proliferation.

\section{Materials and methods}

\section{Cell lines and PBMC from healthy donors}

The following RCC cell lines were used in the study and originally established from RCC patients in Mainz (MZ) or in Halle (Hal): MZ2514RC, MZ1257RC, MZ1790RC,
MZ1774RC, MZ2733RC, MZ2877RC, Hal31RC, Hal162RC, Hal87RC and Hal149RC. The two melanoma cell lines BUF1088Mel and UKRV-Mel-14a have been recently described [21] and were either a kind gift from S. Ferrone (Pittsburgh, USA) or obtained from the European tumor cell line data base (ESTAB project; see www.ebi.ac.uk/ipd/ estdab). Buffy coats were obtained from healthy donor (HD) of the blood bank of the University Hospital Halle. The Institutional Review Board (Ethics Committee) at the University Hospital in Halle (Germany) approved this study.

\section{Reagents}

Monoclonal antibodies (mAb) for flow cytometric analysis were: $\alpha \mathrm{CD} 8, \alpha \mathrm{HLA}-\mathrm{I}$ (clone B9.12.1), $\alpha \mathrm{CD} 40$ and $\alpha \mathrm{ICAM}$ 1 from Beckman Coulter (Krefeld, Germany); $\alpha \mathrm{PD} 1$, $\alpha \mathrm{CD} 80, \alpha \mathrm{NF}-\kappa \mathrm{B}$ (pS529), $\alpha \mathrm{I}_{\kappa} \mathrm{B}$ and $\alpha$ pSTAT6 from Becton Dickinson (Heidelberg, Germany); $\alpha B 7-\mathrm{H} 4$ from AbD serotec; $\alpha \mathrm{ICOS}, \alpha \mathrm{B} 7-\mathrm{H} 4, \alpha \mathrm{B} 7-\mathrm{H} 1, \alpha \mathrm{B} 7-\mathrm{H} 2$ and $\alpha \mathrm{CD} 107 \mathrm{a}$ from ebioscience (Frankfurt, Germany); $\alpha B 7-H 3, \alpha$ TNFRI and fluorokine biotinylated human IL-4 staining kit were used from R\&D systems (Wiesbaden, Germany). Respective isotypes were purchased from BD Bioscience or Beckman Coulter, respectively. The antibodies were used unconjugated and/or as direct conjugates with FITC, Alexa-488, PE, APC or PE-Cy7. Recombinant TNF $\alpha$ and IL-4 for the treatment of RCC cell lines were purchased from ImmunoTools (Friesoythe, Germany).

IL-2 (Proleukine, Pharmacy, University of Halle, Germany), phorbol myristate acetate (PMA), propidiumiodid and ionomycin from Sigma-Aldrich (Steinheim, Germany) were used. $\alpha \mathrm{CD} 8$ microbeads were obtained from Miltenyi Biotech (Gladbach, Germany). RPMI1640 and DMEM were purchased from Invitrogen (Karlsruhe, Germany), XVIVO15 from Lonza (Basel, Switzerland). The fix and perm kit for intracellular stainings was from BD Bioscience.

The following antibodies for cell culture were employed: $\alpha \mathrm{CD} 3$ (clone OKT3) and $\alpha \mathrm{B} 7-\mathrm{H} 1$ (clone MIHI) from ebioscience, purified mIgG1 and mIgG2a from Millipore (Eschborn, Germany) and $\alpha$ HLA-I (clone w6/32) obtained from culture supernatants of hybridomas.

\section{Flow cytometry}

Flow cytometric analyses were essentially performed as recently described [21]. In brief, $1 \times 10^{5}$ cells were stained with fluorescent-labeled antibodies, while dead cells were excluded using PI staining. For determination of the IL-4 receptor expression an indirect staining method using IL-4-biotin followed by Avidin-FITC according to manufacturers' protocols was employed. For intracellular flow cytometric analyses of signal transduction components paraformaldehyde-fixed tumor cells were used, subsequently treated with permeabilizing buffer (methanol) prior to antibody staining. Flow cytometry was performed 
using either a FACSscan ${ }^{\mathrm{Tm}}$, FACSCalibur ${ }^{\mathrm{TM}}$ or a FACSCanto ${ }^{\mathrm{TM}}$ (all Becton Dickinson) or FC500 (Beckman Coulter) flow cytometer and CellQuest $^{\mathrm{Tm}}$ or $\mathrm{CXP}^{\mathrm{Tm}}$ and FlowJo ${ }^{\mathrm{Tm}}$ (Tree Star) software, respectively.

\section{Cytokine treatment of tumor cells}

$3 \times 10^{5}$ tumor cells/well were seeded into 6 well plates in DMEM/10\% FCS. Cytokines (IL-4 at 1000U/ml and TNF $\alpha$ at $800 \mathrm{U} / \mathrm{ml}$ ) were added the following day for $30 \mathrm{~min}$ or 4-72 hrs as indicated for the subsequent analysis.

\section{PCR analysis}

Total cellular RNA from frozen cell pellets was extracted using RNAeasy MiniKit (Qiagen Hilden, Germany) and reversely transcribed into cDNA (Fermentas, St. Leon-Rot Germany) as recently described [22]. Semi-quantitative RT-PCR from cellular RNA was performed using the following oligonucleotide primers: For IL-4 fw: 3' cagttc tacagccaccatgaga 5' rev: $3^{\prime}$ catgatcgtctttagcctttc 5' for, IL4R $\alpha$ fw: 3' tctacttgcgagtggaagatga 5' rev: 3' ctccaaatgttgac tgcatagg 5', TNFa fw: 3' gtgcttgttcctcagcctct 5' rev: 3' gctt gtcactcggggttc 5', TNFRI fw: 3' gccaggagaaacagaacacc 5' rev: $3^{\prime}$ gggataaaaggcaaagacca $5^{\prime}$ and for $\beta$-actin fw: $3^{\prime}$ tcct gtggcatccacgaaact 5' rev: 3' gaagcatttgcggtggacgat 5'. Realtime PCR (Cybr Green, Invitrogen) analysis for B7-H1 and B7-H4 from cellular RNA was performed using the following oligonucleotide primers: $\mathrm{H1}$ : fw: $3^{\prime}$ gaactacctc tggcacatcct 5' rev: 3' gcccattccttcctcttgtc 5', H4: fw: 3' agg cttctctgtgtgtctcttc $5^{\prime}$ rev: $3^{\prime}$ cttgctcttgtttgctcactcc $5^{\prime}$.

\section{Cloning of the reporter gene vector}

Genomic DNA was isolated from the B7-H1 expressing melanoma cell line UKRV-Mel-14a using the QIAamp DNA Mini Kit (Qiagen) according the manufacturers' protocol. The B7-H1 promoter was amplified by PCR with Taq DNA polymerase Kit (Invitrogen) employing the forward primer $5^{\prime}$-AAAGGTACCTAGAAGTTCAG CGCGGGATA-3' and the reverse primer 5'-AAAGGAT CCCAGCGAGCTAGCCAGAGATA-3'. The specific PCR product was purified and cloned into the pMiR REPORT vector (Ambion, Austin, Texas, USA) using the restriction enzymes KpnI and BamHI (Fermentas) replacing the CMV promoter as recently described [23]. For replacing the luciferase (luc) reporter gene by the red fluorescent mcherry protein, the m-cherry sequence was amplified from the pmR-m-cherry vector (Clontech, Mountain View, CA, USA) applying the forward primer 5'-AAAGGATC CATGGTGAGCAAGGGCGAGGA-3' and the reverse primer 5'-AATGTGGTATGGCTGATTAT-3'. The PCR product was digested with BamHI (Fermentas) and SpeI (NEB, Ipswich, MA, USA) and cloned behind the B7-H1 promoter sequence in the pMiR REPORT backbone replacing the luciferase gene. The plasmid map is shown in Additional file 1: Figure S1.

\section{Cell transfection}

The reporter gene plasmid was stably transfected into the melanoma cell line BUF1088Mel using the Effectene Transfection Reagent (Qiagen, Hilden, Germany). Stable transfectants were selected with puromycin (pur) and a pur-resistant batch culture was generated. Transfected cells were cytokine treated as described above and flow cytometric analyses were performed $72 \mathrm{hrs}$ post stimulation.

\section{Tumor-T cell co-culture assays}

Tumor cells were pretreated with cytokines as described above, detached, washed with PBS (3 x times), counted and seeded with $1-2 \times 10^{5}$ into 96 or 24 well plates. Peripheral blood mononuclear cells (PBMC) were obtained by Ficoll gradient from buffy coats of healthy volunteers. T cells were sorted for $\mathrm{CD}^{+}$cells (purity > 98\%) and co-cultivated tumor cells as described [21]. For proliferation assays, $\mathrm{T}$ cells were labeled with CDFA-SE (Lifetechnologies, Darmstadt, Germany) according to manufacturers' instructions) and tumor cells were pretreated with $\alpha \mathrm{HLA}-\mathrm{I}$ or anti-B7-H1 for $30 \mathrm{~min}$ prior to 5 day co-culture assays. Proliferation data are presented as division index (DI) that is the average number of cell divisions that a cell in the original population has undergone. For the determination of IFN $\gamma$ secretion tumor cells were co-cultured with T cells for $4 \mathrm{hrs}$. Cell culture medium for the coculture assays was X-VIVO15.

\section{Detection of cytokine release}

To determine IFN- $\gamma$ secretion of T cells the IFN- $\gamma$ secretion assay (Miltenyi) was performed following the manufacturer's instructions. T cells stimulated with PMA/ ionomycin $(10 \mathrm{ng} / \mathrm{ml}$ and $1 \mu \mathrm{g} / \mathrm{ml})$ served as a positive control. TNF $\alpha$ production of tumor cells was analyzed from culture supernatants using a TNF $\alpha$-specific ELISA according to manufacturer's instructions (ebioscience).

\section{Statistical analysis}

Statistical analyses were performed using Prism 3.0 and depending on controlled data normality distribution Mann Whitney U Test or student's t test was used.

\section{Results}

Cytokine receptor expression as a prerequisite for cytokine activity in RCC cells

The constitutive expression of the IL- 4 and TNF $\alpha$ receptors and and their ligands were determined in RCC cell lines. Using conventional qPCR TNF $\alpha$, but not IL-4 mRNA expression levels were detected in the different RCC cell lines (Figure 1A). Despite prominent TNF $\alpha$ transcription rather low secretion levels of this cytokine were detected in one/five RCC cell lines tested (Figure 1B). In contrast, both the IL-4R $\alpha$ and TNFRI were expressed 




B)
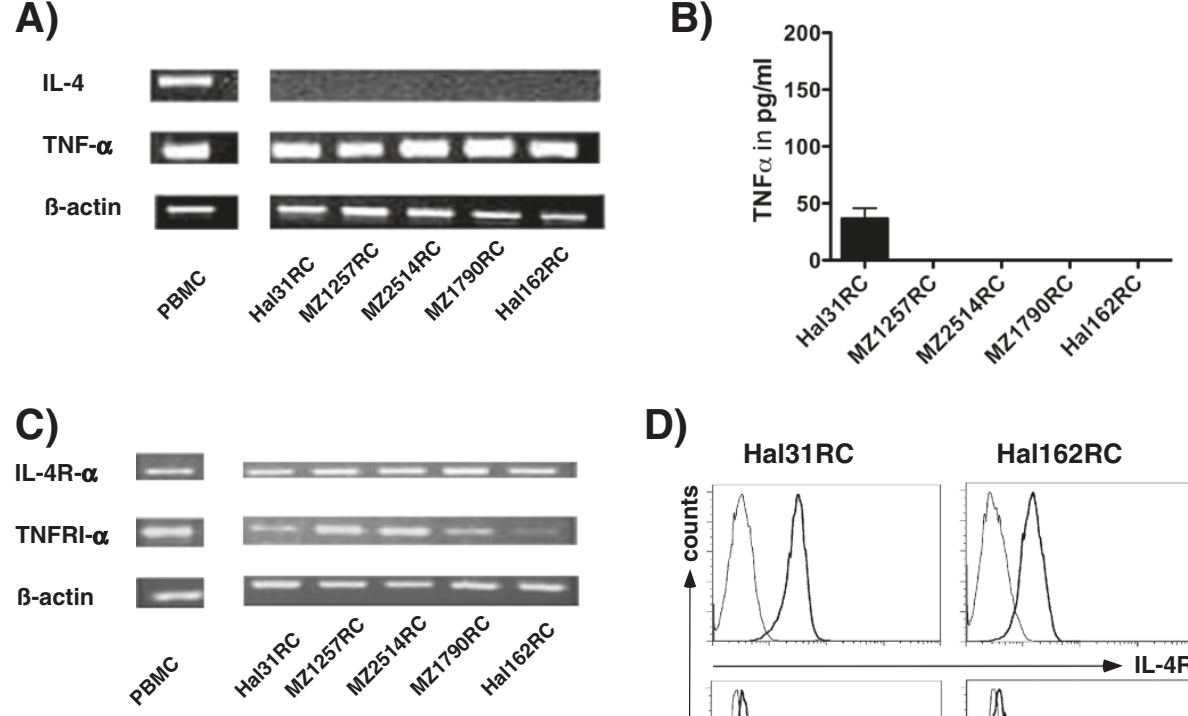

D)

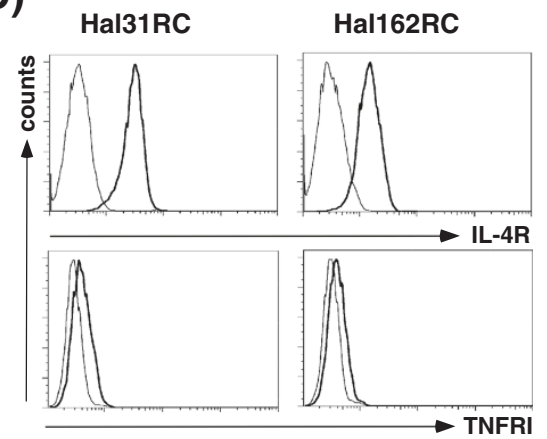

Figure 1 Expression analysis of IL-4, TNFa and their receptors in RCC cell lines. A) Constitutive TNFa mRNA expression, but lack of IL-4 mRNA expression was determined by conventional qPCR in different RCC cell lines (Hal31RC, MZ1257RC, MZ2514RC, MZ1790RC, Hal161RC) and in PBMC, which served as positive control. Representative data of at least 3 different experiments are shown. B) TNFa secretion of different RCC cell lines TNFa secretion was determined in Hal31RC, MZ1257RC, MZ2514RC, MZ1790RC, Hal161RC using ELISA. Representative data out of at least 3 different experiments are shown. C) The IL-4Ra and TNFRI-a expression was determined by qPCR in the different RCC cell lines and in PBMC, which served as positive control. Representative data of at least 3 different experiments are shown. D) Flow cytometric analyses of IL-4R and TNFaRI demonstrated the constitutive expression of IL-4R and TNFRI on Hal31RC and Hal161RC. The results are expressed as histograms. Bold line: staining, thin line: control. TNFRI is stained with an anti-TNFRI-PE labeled antibody, bold line: staining, thin line: isotype control. Representative data of at least 3 different experiments are shown.

at the mRNA (Figure 1C) and protein level (Figure 1D) as determined by qPCR and flow cytometry, respectively.

\section{IL-4 and TNFa synergistically enhance B7-H1 expression in RCC cells}

A heterogeneous, but constitutive cell surface protein expression of $\mathrm{B} 7-\mathrm{H}$ family members was detected in the tested RCC cell lines (Table 1). While B7-H1 to B7-H4 were expressed on all RCC cell lines, the degree of expression was quite diverse with the highest levels for B7$\mathrm{H} 3$ followed by $\mathrm{B} 7-\mathrm{H} 2$ and $\mathrm{B} 7-\mathrm{H} 1$, whereas only weak, but detectable B7-H4 expression levels were found (Table 1). In addition, qPCR analysis revealed low B7-H4 mRNA levels (Additional file 2: Figure S2). 2/3 RCC lines were also weakly positive for B7-DC (data not shown). Upon treatment with either IL-4 and TNF $\alpha$ alone or in combination, the B7-H molecule expression was differentially affected: B7-H4 transcription (data not shown) and protein expression (Figure 2) was unaltered by this cytokine treatment. Despite high constitutive expression levels, a slight cytokine-mediated induction of $\mathrm{B} 7-\mathrm{H} 3$ was shown, which was most prominent in RCC31 upon IL-4 and TNF $\alpha$ treatment. B7-H2 was induced by TNFo, but not by
IL-4 in the RCC cell line analyses, while combined TNF $\alpha$ with IL-4 treatment had no additional effects (Figure 2). The most prominent induction was found for B7-H1 in all RCC cell lines by treatment with either cytokine, while combination treatment caused synergistic effects

Table 1 Constitutive B7-H1-B7-H4 expression in renal cell carcinoma cell lines as determined by FACS, isotype control stainings were implemented

\begin{tabular}{lcccc}
\hline cell lines & B7-H1 & B7-H2 & B7-H3 & B7-H4 \\
\hline Hal31RC & + & + & ++ & $+/-$ \\
Hal78RC & + & + & ++ & $+/-$ \\
Hal149RC & + & + & ++ & $+/-$ \\
Hal162RC & ++ & ++ & ++ & $+/-$ \\
MZ1774RC & + & + & +++ & $+/-$ \\
MZ1790RC & + - & ++ & ++ & $+/-$ \\
MZ1257RC & + & + & ++ & $+/-$ \\
MZ2514RC & + & + & ++ & $+/-$ \\
MZ2733RC & + & + & ++ & $+/-$ \\
MZ2877RC & + & + & ++ & $+/-$ \\
\hline
\end{tabular}

+/- : 5-20\% positive; $+:$ 20-50\% positive; ++ : $>50-100 \%$ positive; $+++: 100 \%$ positive, and staining intensity $>10$ fold to isoytpe control. 

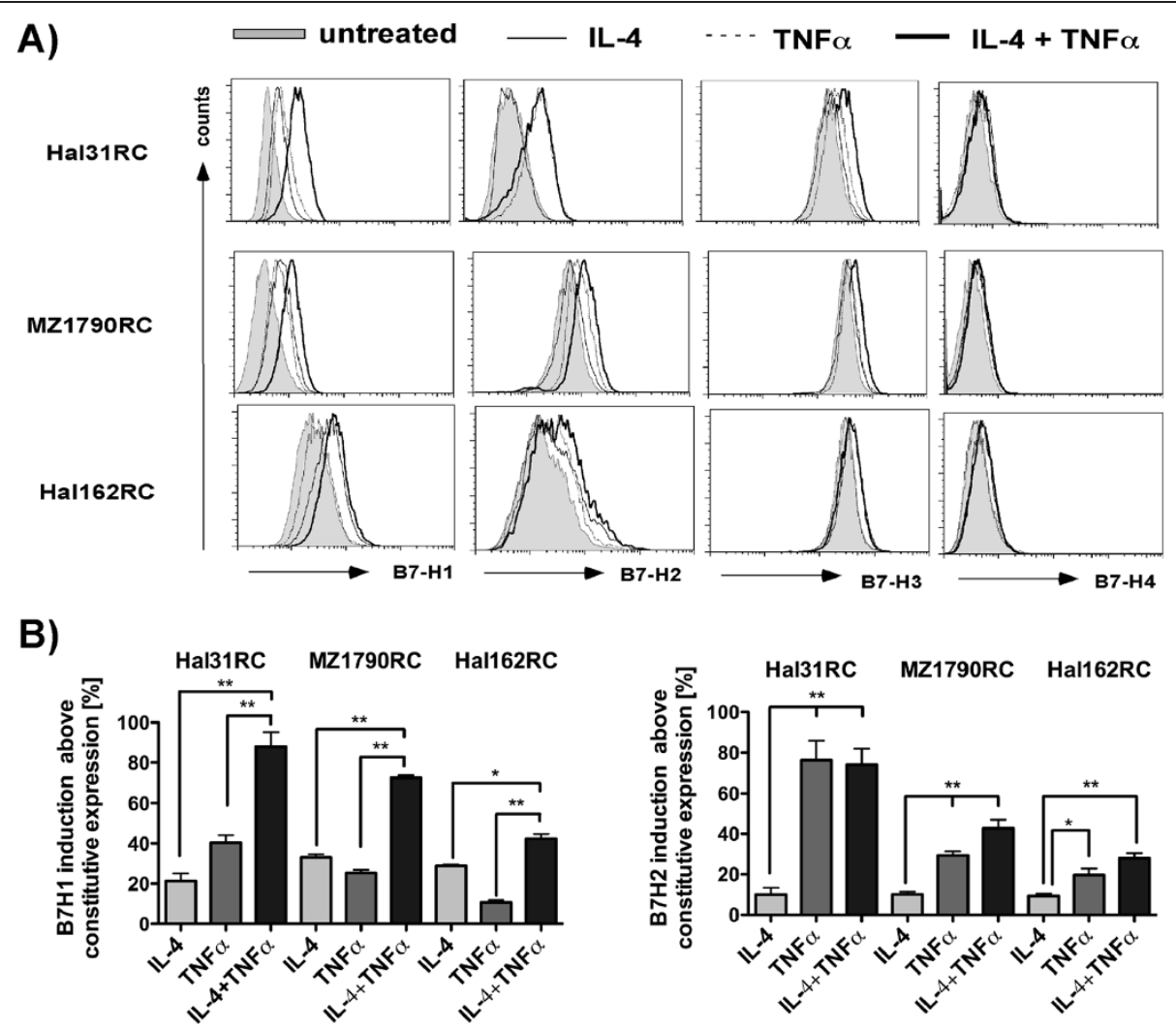

Figure 2 Significant increase of B7-H1 surface expression by IL-4 and TNFa treatment of RCC cell lines. Different RCC cell lines (Hal31RC, Hal161RC, MZ1790RC) were treated with either IL-4 or TNFa alone before B7-H expression was determined by flow cytometry as described in Materials and Methods at 72 hrs. A) Shown are FACS histogram overlay plots for B7-H1, B7-H2, B7-H3 and B7-H4. Each plot shows overlay graphs, depicting constitutive protein expression and expression upon single or combined cytokine treatment. Representative data of at least 3 different experiments are shown. B) Cytokine-mediated induction of $\mathrm{B} 7-\mathrm{H} 1$ and $\mathrm{B} 7-\mathrm{H} 2$ in \% using constitutive expression levels as reference value. Combined data of 3 different experiments are given.

on $\mathrm{B} 7-\mathrm{H} 1$ protein expression (Figure 2 and Figure 3A), with a $<6$ fold increase in RCC31 cells (Figure 3A). Furthermore, IFNY treatment of RCC cells increased B7H1 mRNA and protein expression (data not shown) confirming recent reports [19].

In addition, other cytokines like IFN $\alpha$, IFN $\beta$, TGF $\beta$, IL-6 and IL-10 were tested for their ability to modulate B7-H expression on RCC cells, but none of them altered the expression levels of these molecules. The lack of the cytokine-mediated effects on B7-H family members was specific, since these cytokines modulate e.g. HLA class I molecule expression (data not shown).

\section{Transcriptional control of cytokine-mediated induction of B7-H1}

To identify the kinetics of IL-4- and TNF $\alpha$-mediated regulation of $\mathrm{B} 7-\mathrm{H} 1$ expression $\mathrm{RCC}$ cells were treated for different time points with IL- 4 and TNF $\alpha$ alone or in combination before qPCR and flow cytometry was performed. Already 4 hrs post combined cytokine treatment a significant induction of B7-H1 mRNA was detected
(Figure 3B). Treatment with IL-4 alone only marginally increased the B7-H1 transcript levels throughout the time points tested, whereas TNF $\alpha$ alone induced a significant increase in B7-H1 mRNA levels at 24 hrs post treatment. Combined cytokine treatment had always the strongest impact on B7-H1 mRNA (Figure 3B). An enhanced protein expression was only detected at later time points, with a maximal induction at $72 \mathrm{hrs}$ post cytokine treatment. These results pointed towards a regulation at the transcriptional rather than posttranscriptional level, e.g., by protein stabilization.

In order to test $\mathrm{B} 7-\mathrm{H} 1$ regulation at the transcriptional level in more detail, promoter binding prediction program (TESS) was used to determine direct binding sites for STAT6 (downstream of IL-4 signaling) and NFKB (p65, downstream of TNFa) on the B7-H1 promoter (-952 to $-1 \mathrm{bp}$ before transcript start). A weak binding site for STAT6 (TTACAAGAA) and two overlapping high affinity binding sites for NFKB (GGAAAGTCCA; AGGAAAGTCCAAC) were found in the B7-H1 promoter. One $\mathrm{NF \kappa B}$ binding site in the $\mathrm{B} 7-\mathrm{H} 1$ promoter 




has been shown to control B7-H1 expression in renal tubular cells [24].

Based on this finding B7-H1 promoter studies were performed [25]. The wild type B7-H1 promoter construct hooked to the mCherry fluorescent protein was stably transfected into BUF088Mel cells (Additional file 1: Figure S1). Transfectants were subsequently left untreated or treated with either cytokine (IL-4 or TNF $\alpha$ ) alone or in combination before promoter activity was determined $72 \mathrm{hrs}$ later. As shown in Figure 3C, an enhanced B7-H1 promoter activity as determined by flow cytometry of the mCherry fluorescence was found upon single and more pronounced upon combined treatment with IL- 4 and TNFo. This suggests a transcriptional upregulation of $\mathrm{B} 7-\mathrm{H} 1$, which might be mediated by activation of STAT6 and NFкB.

Alterations in pSTAT6, NFKB, LFA-1, CD40 and HLA class I antigen expression levels upon treatment of RCC cells with IL-4 and TNFa

In addition to the regulation of B7-H molecules by cytokine treatment downstream signal cascade components and other processes known to be of relevance for the $\mathrm{T}$ 
cell/tumor interaction and the growth behavior of RCC cells were investigated.

A growth inhibition of RCC cells was detected upon IL-4 addition, which was not further pronounced in the presence of TNF $\alpha$ (Additional file 3: Figure S3). In contrast, TNF $\alpha$ alone had no influence on the cell proliferation, which is in discrepancy to earlier published data showing an increased proliferation upon TNF $\alpha$ treatment, but a strong influence of the culture media conditions were found [26].

Following IL-4 treatment alone or in combination with TNF $\alpha$ phosphorylation of STAT6, a key signal molecule downstream the IL-4 receptor, was detected by flow cytometry (Figure 4A). A known key downstream effector of TNF $\alpha$ signaling is represented by $N F K B$. An enhanced expression and activation of $N F \kappa B$ was found in TNF $\alpha$ as well as TNF $\alpha$ - and IL-4-treated RCC cells (Figure 4A). Next to the upregulation of $N F \kappa B$ the inhibitory subunit of $N F \kappa B$, named IkB, was downregulated upon TNF $\alpha$ treatment in RCC cells (data not shown). Downregulation/degradation of IкB as a part of the classical NFкB pathway activation has been described earlier [27].
Additional important molecules for $\mathrm{T}$ cell/tumor communication are CD40, a costimulator of the TNF-R family, the adhesion molecule CD54 (LFA-1) and HLA class I antigens. As shown in Figure 4B all these surface molecules were upregulated by the treatment of RCC cells with IL-4 and TNF $\alpha$, either alone or in combination. The combined treatment of IL-4 and TNFo had an additive (CD40, HLA class I) or a synergistic effect (LFA-1) on the protein expression, respectively (Figure 4B).

\section{B7-H1 blocks allospecific $\mathrm{T}$ cell proliferation}

B7-H1 has been shown to modulate $\mathrm{T}$ cell responses. $[19,28]$ To test the functional consequences of increased B7-H1 on RCC cells upon IL-4 and TNF $\alpha$ treatment coculture assays of tumor cells with allospecific $\mathrm{T}$ cells were performed. A decreased $\mathrm{CD}^{+} \mathrm{T}$ cell proliferation was detected upon co-cultivation of $\mathrm{T}$ cells with IL-4 pretreated as well as with IL-4 and TNF $\alpha$ pretreated tumor cells (Figure 5A and B). The direct influence of both cytokines on $\mathrm{T}$ cells was eliminated by 3 times washing of cytokine-treated tumor cells, prior to coculture assays. The decreased proliferation of $\mathrm{CD}^{+} \mathrm{T}$

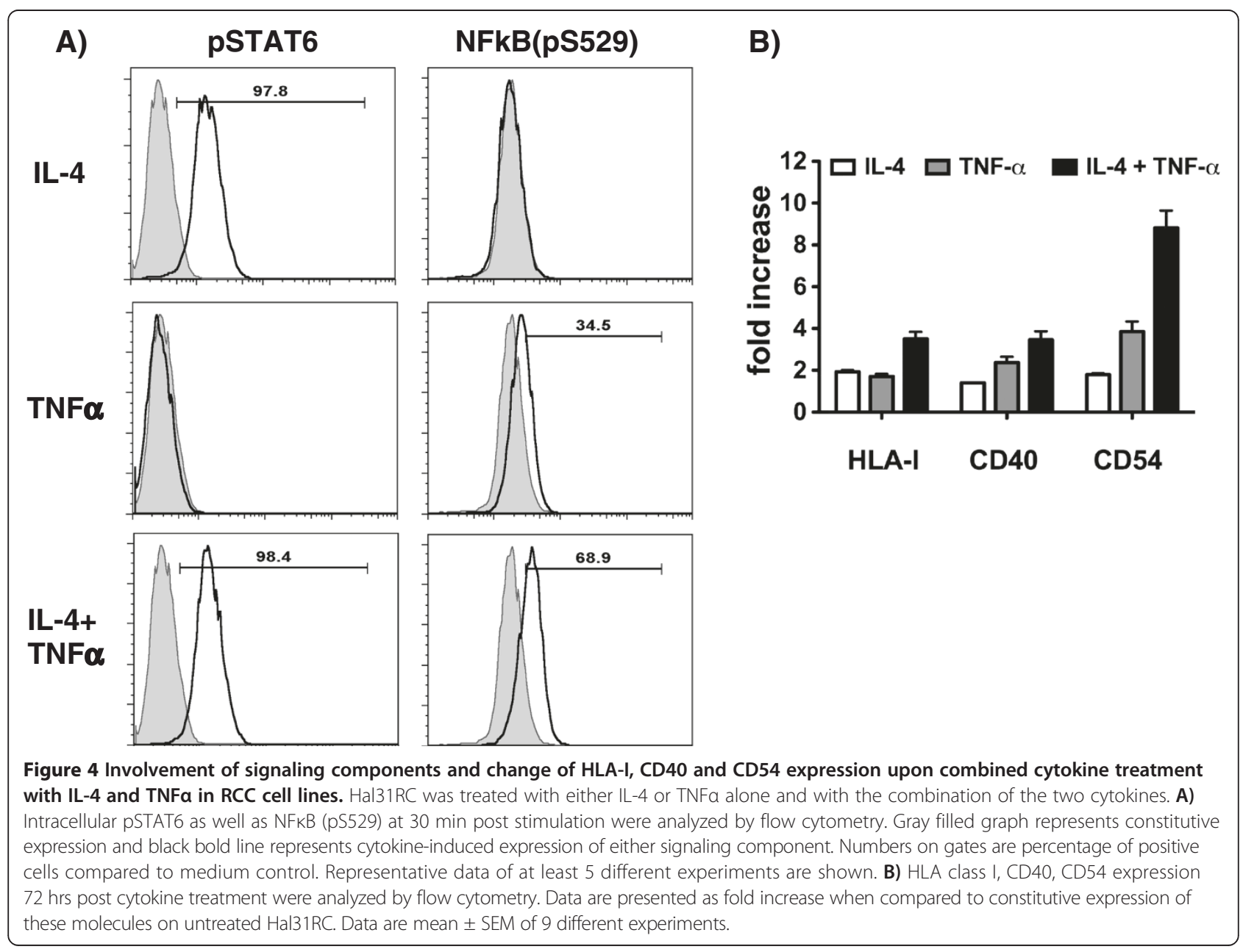




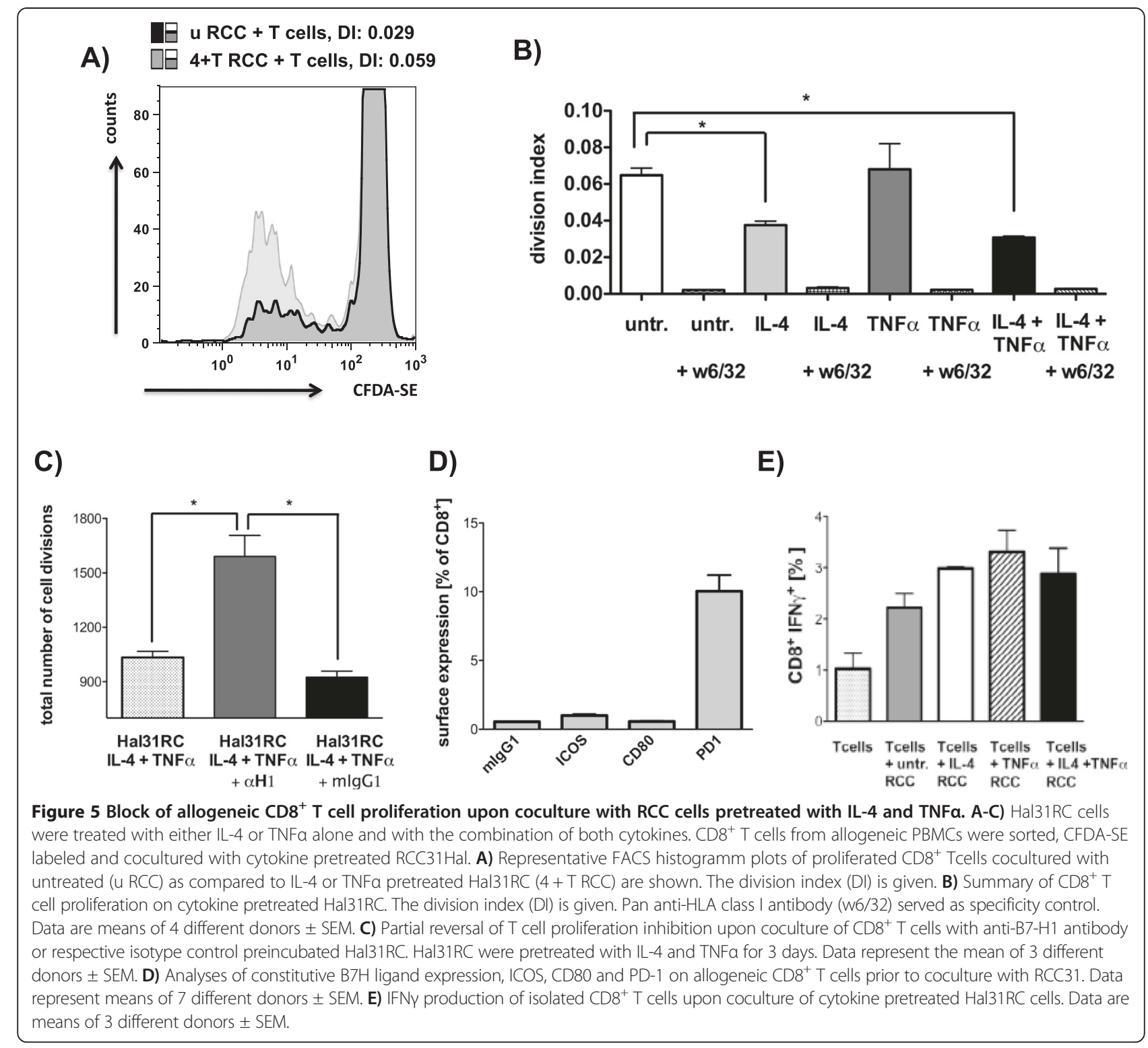

cells upon co-culture with IL-4- and TNF $\alpha$-pretreated tumor cells could be partially converted by the use of an anti-B7-H1 blocking antibody as proof for the inhibitory role of $\mathrm{B} 7-\mathrm{H} 1$ on tumor cells (Figure $5 \mathrm{C}$ ).

To identify the possible binding partner of $\mathrm{B} 7-\mathrm{H} 1$ on $\mathrm{T}$ cells, an anti-PD1 antibody was used for staining to detect the most likely candidate PD1. Indeed, PD1 was expressed in $10.05 \pm 1.17 \%$ of $\mathrm{CD}^{+} \mathrm{T}$ cells analyzed (Figure 5D). Since CD80 expression on T cells has been postulated [29] and CD80 can additionally bind B7-H1 [30] its CD80 expression was determined on T cells. In addition, since $\mathrm{B} 7-\mathrm{H} 2$ expression is known to be increased upon treatment with TNF $\alpha$, ICOS, the ligand of B7- $\mathrm{H} 2$ was analyzed on $\mathrm{CD}^{+} \mathrm{T}$ cells prior to co-culture assays. As shown in Figure 5D, CD80 and ICOS were only very weakly expressed on $\mathrm{CD} 8^{+} \mathrm{T}$ cells.
Important $\mathrm{CD}^{+} \mathrm{T}$ cell effector functions are cytokine production and the ability to kill target cells. As determined flow cytometry IFN $\gamma$ secretion by $\mathrm{CD} 8^{+} \mathrm{T}$ cells was unaltered upon co-culture with cytokine-treated RCC cells (Figure 5E). Furthermore, the killing ability of $\mathrm{CD} 8^{+} \mathrm{T}$ cells was determined by measurement of CD107a degranulation, $\mathrm{CD}^{+} \mathrm{T}$ cells upregulated $\mathrm{CD} 107 \mathrm{a}$ expression upon co-culture with RCC cells, but no specific changes with respect to co-culture with cytokine pretreated tumor cells were found (data not shown).

\section{Discussion}

The present study was undertaken to discover the distribution and regulation of $\mathrm{B} 7-\mathrm{H}$ family members in RCC by cytokines released from immune cells of the tumor microenvironment. Interesting, a synergistic increase of 
B7-H1 surface expression in RCC cells upon treatment with IL-4 and TNF $\alpha$ was found. As early as 4 hrs after treatment, B7-H1 mRNA was significantly enhanced resulting in 6- fold increase in protein surface expression by $72 \mathrm{hrs}$ and was mediated by an upregulation of the B7-H1 promoter activity by combined IL- 4 and TNF $\alpha$ treatment. In addition, the increase in $\mathrm{B} 7-\mathrm{H} 1$ protein surface expression on RCC cells was associated with a decreased allospecific $\mathrm{T}$ cell proliferation upon coculture experiments.

Detailed analysis showed a constitutive, but variable surface expression of $\mathrm{B} 7-\mathrm{H} 1$ to $\mathrm{B} 7-\mathrm{H} 4$ molecules on RCC cells. Expression of B7-H1, B7-H3 and B7-H4 in situ has been correlated with a worse clinical outcome of RCC patients $[9,31,32]$. In all tested RCC cell lines, B7-H4 was rather weakly expressed. In contrast B7-H3 was strongly expressed on RCC cell lines. To the best of our knowledge, we are the first to show $\mathrm{B} 7-\mathrm{H} 2$ expression on RCC cells. There exist random reports showing expression of this molecule in human tumors such as glioblastoma [33] and melanoma [34]. B7-H2 on glioma cells leads to an increase in T cell-mediated anti-tumor immunity [35].

In addition, $\mathrm{B} 7-\mathrm{H} 1$ expression on RCC cells was confirmed with a weak or intermediate expression level by all RCC cell lines tested. Testing of the constitutive cytokine expression revealed a weak TNF $\alpha$ production by one RCC cell line, while all others were negative. These data are in line with earlier reports describing that some RCC cells are able to produce TNFa [36]. Furthermore, RCC cells in our study lack IL-4 expression thereby confirming previous published data [37]. A prerequisite to respond to a particular cytokines is the expression of the respective cytokine receptors. Both the IL-4R as well as TNFRI expression was found on all RCC cells tested. TNF $\alpha$ acts via TNFRI and II both expressed on RCC cells [38]. IL-4R expression on RCC cells in vitro and in situ has been demonstrated before [39]. Interestingly, structural differences for IL-4R on RCC cells when compared to immune cells exist, which might partially explain the differential outcome of IL-4 action in these cells [37]. Most of the RCC cell lines tested in the present study showed a very good and reliable response to IL-4 and TNF $\alpha$ treatment as demonstrated by phosphorylation of STAT6, enhancement of pNFkB and downregulation of IkB.

Given the importance of $\mathrm{B} 7-\mathrm{H}$ molecules for the outcome of RCC patients and the presence of cytokines in the tumor microenvironment, the regulation of these family members upon treatment with various cytokines was determined. As already described, upregulation of B7-H1 expression by IFNY was confirmed [19]. In addition the most prominent effect on the regulation of B7-H1 was found using combined IL-4 and TNF $\alpha$ treatment. B7-H1 was transcriptionally controlled by these cytokines. B7-H2 was only upregulated by TNF $\alpha$ treatment, but not by IL-4.

IL-4 and TNFa can both be produced by different immune cells and thus represent components of the tumor microenvironment. In RCC TNF $\alpha$ is produced by tumorassociated macrophages (TAM) [40]. TAMs can be subdivided into classical M1 phenotype macrophages that produce and dependent on proinflammatory cytokines, such as TNF $\alpha$ and into alternative M2 phenotype macrophages [41]. M2 macrophages are characterized by the production of IL-10, TGF- $\beta$ and are induced by IL- 4 . The ratio of M1/ M2 TAMs together with the number and phenotype of dendritic cells, myeloid derived suppressor cells (MDSC) and the Th1/Th2 balance determine the cytokine milieu and thereby the anti-tumor response in the tumor microenvironment. Already 15 years ago $\mathrm{CD} 4^{+}$Th cells of the Th1 (predominantly IFNY) and Th2 (predominantly IL-4) cells as well as $\mathrm{CD}^{+} \mathrm{T}$ cells have been shown to play a key role for an effective anti-tumor response. Furthermore, IL-4 has a tremendous impact on the anti-tumor immunity by shifting the Th1/Th2 balance [42]. The importance for IL-4 in RCC is demonstrated by the existence of a functional polymorphism in the IL-4 gene $(-590 \mathrm{~T})$ leading to an enhanced expression of this cytokine, which is correlated with an increased risk of developing RCC [43] and a decreased survival [44] when compared to RCC patients carrying the other haplotype $(-590 \mathrm{C})$. In contrast to earlier reports, IL-4 can reduce tumor growth suggesting that the time point and local distribution of high IL-4 levels have an impact on RCC progression. Of importance, microarray data reveal a positive correlation of $\mathrm{B} 7-\mathrm{H} 1$ with TNF $\alpha$, NFkB and STAT6 (http://r2.amc.nl) in kidney tumor tissue in vivo, nicely supporting our data of a linked B7-H1 expression with these cytokines.

In addition to IFN- $\gamma$, the regulation of $\mathrm{B} 7-\mathrm{H}$ expression by cytokines has been studied earlier, but mostly on immune cells and not on RCC cells. Kryzek and coauthors showed an increase of B7-H4 in TAMs upon treatment with IL-6 or IL-10 [45]. Similar to our findings TNF $\alpha$ upregulates $\mathrm{B} 7-\mathrm{H} 2$ on embryonic fibroblasts [46] and endothelial cells [47], while IL-4 did not modulate $\mathrm{B} 7-\mathrm{H} 2$ and the combined treatment had no additional effect [47]. Interestingly, on human endothelial cells TNF $\alpha$ together with IFNY synergistically affect induction, whereas TNF $\alpha$ alone did not induce any B7-H1 expression [48].

As already proposed by and confirmed in this study combined IL- 4 and TNF $\alpha$ treatment exerts a synergistic effect on the increase of HLA class I antigen expression in RCC cells, which might enhance $\mathrm{T}$ cell-based antitumor responses [13]. This was further supported by an increased expression of components of the APM leading to increased HLA class I surface antigen expression in RCC cells upon IFN- $\gamma$ treatment [30]. Since another 
hallmark of effective $\mathrm{T}$ cell response is cell adhesion, ICAM1 expression was analyzed. ICAM1 expression was highly upregulated upon combined IL-4 and TNF $\alpha$ treatment, which can support $\mathrm{T}$ cell/tumor interaction. This is in line with published data demonstrating that TNF $\alpha$ induces ICAM1 expression [49].

As functional consequences of cytokine-mediated enhanced $\mathrm{B} 7-\mathrm{H} 1$ on RCC tumor cells, a decreased allospecific $\mathrm{CD}^{+} \mathrm{T}$ cell proliferation was found, which could be partially converted by addition of an anti-B7-H1 antibody. Since PD1 was the only substantially expressed receptor on the $\mathrm{CD} 8^{+} \mathrm{T}$ cells used in the co-culture assays, it is therefore most likely responsible for this effect. This assay nicely resembles the in vivo situation, since enhanced PD1 expression on tumor-infiltrating immune cells has been found in RCC and could be associated with poor patients' prognosis [50]. However, IFN- $\gamma$ and CD107a mobilization was not altered in $\mathrm{CD}^{+} \mathrm{T}$ cells upon co-culture with cytokine pre-treated tumor cells. An inhibitory effect of $\mathrm{B} 7-\mathrm{H} 1$ on $\mathrm{CD} 8^{+} \mathrm{T}$ cells has already been described in different studies. A block in $\mathrm{T}$ cell proliferation owing to $\mathrm{B} 7-\mathrm{H} 1$ has been shown before with overexpression or blocking of $\mathrm{B} 7-\mathrm{H} 1$, but not with cytokine-pretreated cells $[51,52,20]$. Additionally, a direct decrease of $\mathrm{CD}^{+} \mathrm{T}$ cell killing and cytokine production upon co-culture assays with anti-B7-H1 blocking antibody for human TCR tg $\mathrm{CD}^{+} \mathrm{T}$ cells in RCC has been found [19]. On the other hand, Dong and coworkers (2002) showed that TCR tg human CTL are equally able to kill $\mathrm{B} 7-\mathrm{H} 1$ over-expressing melanoma cells, but a B7-H1 dependent induction of $\mathrm{T}$ cell apoptosis was detected [28]. Together with the findings of this study the data demonstrate the powerful influence of B7-H1 on the modulation of different T cell effector responses, which highly appear to depend on the co-culture systems chosen.

The observed block of $\mathrm{T}$ cell proliferation on $\mathrm{CD}^{+} \mathrm{T}$ cells co-cultured with single IL-4-treated RCC cells could be due to an additionally interaction of PD1 on T cells with its second ligand B7-DC. A weak constitutive expression of B7-DC was found that could be also a subject to regulation by IL-4 similar as shown for macrophages [53] possibly not to TNF $\alpha$ as analyzed for monocytes [52]. B7-DC has been shown to inhibit human $\mathrm{T}$ cell proliferation by PD1 binding [51].

High dose TNF $\alpha$ has been used to treat solid tumors, but due to many side effects upon systemic administration the success rate has been rather low, and strategies to administer this cytokine more locally had been developed for e.g. melanoma patients [54], but have not been used to treat RCC.

Phase II clinical trials using IL-4 for the treatment of RCC were not beneficial for these patients $[16,18]$. This might be at least partially explained by the decreased $\mathrm{T}$ cell proliferation capacity upon co-culture assays with IL-4-treated RCC cells. TNF $\alpha$ alone had no effect on $\mathrm{T}$ cell effector responses in the setting used in our study, although TNF $\alpha$ treatment exerted beneficial anti-tumor effects in a xenograft mouse model with RCC tumors [12].

\section{Conclusion}

Concluding the data, this study showed for the first time a detailed analysis of $\mathrm{B} 7-\mathrm{H}$ molecule regulation upon cytokine treatment in RCC. B7-H1 exhibited the strongest sensitivity to IL-4 and TNF $\alpha$ by a synergistic upregulation in RCC cells and is controlled at the transcriptional level by direct promoter targeting. The importance of this B7-H1 induction is demonstrated by an inhibition of $\mathrm{T}$ cell proliferation thereby contributing to the proposed significance of B7-H1 in cancer immunity. The study furthermore supports the rational of using B7-H1/PD1 checkpoint antibodies for the treatment of tumor patients.

\section{Additional files}

Additional file 1: Figure S1. Reporter gene plasmid map for $\mathrm{B} 7-\mathrm{H} 1$.

Additional file 2: Figure S2. B7-H4 mRNA as determined by real time $\mathrm{PCR}$ is given. Transcript numbers are calculated using a $\beta$-actin and $\mathrm{B} 7-\mathrm{H} 4$ plasmid as template. Representative data from 2 experiments are shown.

Additional file 3: Figure S3. Growth inhibition of cells treated with IL-4 and the combination of IL-4+TNFa for 3 different RCC cell lines is shown. Same numbers of cells were seeded into wells and cells were equally detached and counted using trypan blue exclusion at the end of culture time (72hrs). Combined data of three different experiments are shown.

\section{Abbreviations}

APM: Antigen processing machinery; CTL: Cytotoxic T lymphocyte; NFkB: Nuclear factor kappa B; IFN: Interferon; IL: Interleukin; luc: Luciferase; mAb: Monoclonal antibodies; MHC: Major histocompatible complex; RCC: Renal cell carcinoma; STAT: Signal transducer and activator of transcription; TAA: Tumor-associated antigens; TAM: Tumor-associated macrophages; TCR: T cell receptor; TNF: Tumor necrosis factor.

\section{Competing interests}

The authors declare that they have no competing interests.

\section{Authors' contributions}

DQ carried out main part of experiments, interpretation of results and wrote the manuscript, SJ-B carried out the promoter studies, UM performed part of the FACS analysis and the real time PCR experiments, BSC performed part of the $T$ cell assays and BSe conceived of the study, participated in its design and coordination and was involved in writing the manuscript. All authors read and approved the final manuscript.

\section{Acknowledgments}

The authors would like to thank Jürgen Bukur, Chiara Massa and Dagmar Riemann for discussions, experimental assistance and generation of RCC cell lines. In addition, we would like to thank Sylvi Magdeburg for excellent secretarial work

\section{Grant support}

This work was sponsored by a grant from the Wilhelm Roux Program of the Martin Luther University Halle-Wittenberg (D. Q.), Deutsche Forschungsgemeinschaft, GRK 1591 (B.S.) and a grant from the Mildred Scheel Foundation, Bonn (B. S., D. Q.). 
Received: 25 November 2013 Accepted: 28 April 2014

Published: 30 May 2014

\section{References}

1. Jemal A, Bray F, Center MM, Ferlay J, Ward E, Forman D: Global cancer statistics. CA Cancer J Clin 2011, 61:69-90.

2. Organization WH: mortality database: http://globocan.iarc.fr/Pages/ fact_sheets_cancer.aspx 07/05/2013.

3. Escudier B: Emerging immunotherapies for renal cell carcinoma. Ann Oncol 2012, 23(8):35-40.

4. Seliger B, Quandt D: The expression, function, and clinical relevance of B7 family members in cancer. Cancer Immunol Immunother 2012, 61:1327-1341.

5. Azuma T, Yao S, Zhu G, Flies AS, Flies SJ, Chen L: B7-H1 is a ubiquitous antiapoptotic receptor on cancer cells. Blood 2008, 111:3635-3643.

6. Kaifu T, Escaliere B, Gastinel LN, Vivier E, Baratin M: B7-H6/NKp30 interaction: a mechanism of alerting NK cells against tumors. Cell Mol Life Sci 2011, 68:3531-3539.

7. Greenwald RJ, Freeman GJ, Sharpe AH: The B7 family revisited. Annu Rev Immunol 2005, 23:515-548

8. Tang PA, Heng DY: Programmed death 1 pathway inhibition in metastatic renal cell cancer and prostate cancer. Curr Oncol Rep 2013, 15:98-104.

9. Thompson RH, Kuntz SM, Leibovich BC, Dong H, Lohse CM, Webster WS, Sengupta S, Frank I, Parker AS, Zincke H, Blute ML, Sebo TJ, Cheville JC, Kwon ED: Tumor $\mathrm{B} 7-\mathrm{H} 1$ is associated with poor prognosis in renal cell carcinoma patients with long-term follow-up. Cancer Res 2006, 66:3381-3385.

10. Sanjmyatav J, Steiner T, Wunderlich H, Diegmann J, Gajda M, Junker K: A specific gene expression signature characterizes metastatic potential in clear cell renal cell carcinoma. J Urol 2011, 186:289-294.

11. Smith AJ, Humphries SE: Cytokine and cytokine receptor gene polymorphisms and their functionality. Cytokine Growth Factor Rev 2009, 20:43-59.

12. Bauer S, Oosterwijk-Wakka JC, Adrian N, Oosterwijk E, Fischer E, Wuest T, Stenner F, Perani A, Cohen L, Knuth A, Divgi C, Jager D, Scott AM, Ritter G, Old $L$, Renner C: Targeted therapy of renal cell carcinoma: synergistic activity of cG250-TNF and IFNg. Int J Cancer 2009, 125:115-123.

13. Hoon DS, Okun E, Banez M, Irie RF, Morton DL: Interleukin 4 alone and with gamma-interferon or alpha-tumor necrosis factor inhibits cell growth and modulates cell surface antigens on human renal cell carcinomas. Cancer Res 1991, 51:5687-5693.

14. Ikemoto S, Narita K, Yoshida N, Wada S, Kishimoto T, Sugimura K, Nakatani T: Effects of tumor necrosis factor alpha in renal cell carcinoma. Oncol Rep 2003, 10:1947-1955.

15. Bockorny B, Dasanu CA: Intrinsic immune alterations in renal cell carcinoma and emerging immunotherapeutic approaches. Expert Opin Biol Ther 2013, 13:911-925.

16. Margolin K, Aronson FR, Sznol M, Atkins MB, Gucalp R, Fisher RI, Sunderland M, Doroshow JH, Ernest ML, Mier JW: Phase II studies of recombinant human interleukin-4 in advanced renal cancer and malignant melanoma. J Immunother Emphasis Tumor Immunol 1994, 15:147-153.

17. Motzer RJ, Russo P, Nanus DM, Berg WJ: Renal cell carcinoma. Curr Probl Cancer 1997, 21:185-232

18. Whitehead RP, Lew D, Flanigan RC, Weiss GR, Roy V, Glode ML, Dakhil SR, Crawford ED: Phase II trial of recombinant human interleukin-4 in patients with advanced renal cell carcinoma: a Southwest oncology group study. J Immunother 2002, 25:352-358.

19. Blank C, Kuball J, VoelkI S, Wiendl H, Becker B, Walter B, Majdic O, Gajewski TF, Theobald M, Andreesen R, Mackensen A: Blockade of PD-L1 (B7-H1) augments human tumor-specific $\mathrm{T}$ cell responses in vitro. Int J Cancer 2006, 119:317-327.

20. Kondo A, Yamashita T, Tamura H, Zhao W, Tsuji T, Shimizu M, Shinya E, Takahashi H, Tamada K, Chen L, Dan K, Ogata K: Interferon-gamma and tumor necrosis factor-alpha induce an immunoinhibitory molecule, B7-H1, via nuclear factor-kappaB activation in blasts in myelodysplastic syndromes. Blood 2010, 116:1124-1131

21. Quandt D, Fiedler E, Boettcher D, Marsch W, Seliger B: B7-h4 expression in human melanoma: its association with patients' survival and antitumor immune response. Clin Cancer Res 2011, 17:3100-3111.

22. Wulfanger J, Biehl $K$, Tetzner A, Wild $P$, Ikenberg $K$, Meyer S, Seliger B: Heterogeneous expression and functional relevance of the ubiquitin carboxyl-terminal hydrolase L1 in melanoma. Int J Cancer 2013, 133:2522-2532.
23. Bukur J, Herrmann F, Handke D, Recktenwald C, Seliger B: Identification of E2F1 as an important transcription factor for the regulation of tapasin expression. J Biol Chem 2010, 285:30419-30426.

24. Chen Y, Zhang J, Guo G, Ruan Z, Jiang M, Wu S, Guo S, Fei L, Tang Y, Yang C, Jia Z, Wu Y: Induced B7-H1 expression on human renal tubular epithelial cells by the sublytic terminal complement complex C5b-9. Mol Immunol 2009, 46:375-383.

25. Steven A, Leisz S, Massa C, lezzi M, Lattanzio R, Lamolinara A, Bukur J, Muller A, Hiebl B, Holzhausen HJ, Seliger B: HER-2/neu mediates oncogenic transformation via altered CREB expression and function. Mol Cancer Res 2013, 11:1462-1477.

26. Falkensammer C, Johrer K, Gander H, Ramoner R, Putz T, Rahm A, Greil R, Bartsch G, Thurnher M: IL-4 inhibits the TNF-alpha induced proliferation of renal cell carcinoma (RCC) and cooperates with TNF-alpha to induce apoptotic and cytokine responses by RCC: implications for antitumor immune responses. Cancer Immunol Immunother 2006, 55:1228-1237.

27. Waddick KG, Uckun FM: Innovative treatment programs against cancer. I. Ras oncoprotein as a molecular target. Biochem Pharmacol 1998, 56:1411-1426.

28. Dong H, Strome SE, Salomao DR, Tamura H, Hirano F, Flies DB, Roche PC, Lu J, Zhu G, Tamada K, Lennon VA, Celis E, Chen L: Tumor-associated B7-H1 promotes T-cell apoptosis: a potential mechanism of immune evasion. Nat Med 2002, 8:793-800.

29. Kochli C, Wendland T, Frutig K, Grunow R, Merlin S, Pichler WJ: CD80 and CD86 costimulatory molecules on circulating T cells of HIV infected individuals. Immunol Lett 1999, 65:197-201.

30. Butte MJ, Keir ME, Phamduy TB, Sharpe AH, Freeman GJ: Programmed death-1 ligand 1 interacts specifically with the B7-1 costimulatory molecule to inhibit T cell responses. Immunity 2007, 27:111-122.

31. Crispen PL, Sheinin Y, Roth TJ, Lohse CM, Kuntz SM, Frigola X, Thompson $\mathrm{RH}$, Boorjian SA, Dong H, Leibovich BC, Blute ML, Kwon ED: Tumor cell and tumor vasculature expression of $\mathrm{B} 7-\mathrm{H} 3$ predict survival in clear cell renal cell carcinoma. Clin Cancer Res 2008, 14:5150-5157.

32. Krambeck AE, Thompson RH, Dong H, Lohse CM, Park ES, Kuntz SM, Leibovich BC, Blute ML, Cheville JC, Kwon ED: B7-H4 expression in renal cell carcinoma and tumor vasculature: associations with cancer progression and survival. Proc Natl Acad Sci U S A 2006, 103:10391-10396.

33. Schreiner B, Wischhusen J, Mitsdoerffer M, Schneider D, Bornemann A, Melms A, Tolosa E, Weller M, Wiendl H: Expression of the B7-related molecule ICOSL by human glioma cells in vitro and in vivo. Glia 2003, 44:296-301.

34. Strauss L, Bergmann C, Szczepanski MJ, Lang S, Kirkwood JM, Whiteside TL: Expression of ICOS on human melanoma-infiltrating CD4 + CD25highFoxp3+ T regulatory cells: implications and impact on tumor-mediated immune suppression. J Immunol 2008, 180:2967-2980.

35. Wallin JJ, Liang L, Bakardjiev A, Sha WC: Enhancement of CD8+ T cell responses by ICOS/B7h costimulation. J Immunol 2001, 167:132-139.

36. Mizutani $Y$, Bonavida B, Nio Y, Yoshida O: Overcoming TNF-alpha and drug resistance of human renal cell carcinoma cells by treatment with pentoxifylline in combination with TNF-alpha or drugs: the role of TNF-alpha mRNA downregulation in tumor cell sensitization. J Urol 1994, 151:1697-1702.

37. Obiri NI, Puri RK: Characterization of interleukin-4 receptors expressed on human renal cell carcinoma cells. Oncol Res 1994, 6:419-427.

38. Al-Lamki RS, Sadler TJ, Wang J, Reid MJ, Warren AY, Movassagh M, Lu W, Mills IG, Neal DE, Burge J, Vandenebeele P, Pober JS, Bradley JR: Tumo necrosis factor receptor expression and signaling in renal cell carcinoma. Am J Pathol 2010, 177:943-954

39. Varricchio F, Obiri NI, Haas GP, Puri RK: Immunostaining of interleukin-4 receptor on human renal cell carcinoma. Lymphokine Cytokine Res 1993, 12:465-469.

40. Ikemoto S, Yoshida N, Narita K, Wada S, Kishimoto T, Sugimura K, Nakatani T: Role of tumor-associated macrophages in renal cell carcinoma. Oncol Rep 2003, 10:1843-1849.

41. Santoni M, Massari F, Amantini C, Nabissi M, Maines F, Burattini L, Berardi R, Santoni G, Montironi R, Tortora G, Cascinu S: Emerging role of tumorassociated macrophages as therapeutic targets in patients with metastatic renal cell carcinoma. Cancer Immunol Immunother 2013 62:1757-1768

42. Pardoll DM, Topalian SL: The role of CD4+ T cell responses in antitumor immunity. Curr Opin Immunol 1998, 10:588-594. 
43. Zhu J, Ju X, Yan F, Qin C, Wang M, Ding Q, Zhang Z, Yin C: Association of IL-4 -590 T>C polymorphism and risk of renal cell carcinoma in a Chinese population. Int I Immunogenet 2010, 37:459-465.

44. Kleinrath T, Gassner C, Lackner P, Thurnher M, Ramoner R: Interleukin-4 promoter polymorphisms: a genetic prognostic factor for survival in metastatic renal cell carcinoma. J Clin Oncol 2007, 25:845-851.

45. Kryczek I, Zou L, Rodriguez P, Zhu G, Wei S, Mottram P, Brumlik M, Cheng P, Curiel T, Myers L, Lackner A, Alvarez X, Ochoa A, Chen L, Zou W: B7-H4 expression identifies a novel suppressive macrophage population in human ovarian carcinoma. J Exp Med 2006, 203:871-881.

46. Swallow MM, Wallin JJ, Sha WC: B7h, a novel costimulatory homolog of B7.1 and B7.2, is induced by TNFalpha. Immunity 1999, 11:423-432.

47. Youngnak-Piboonratanakit $\mathrm{P}$, Tsushima F, Otsuki N, Igarashi H, Omura K, Azuma M: Expression and regulation of human CD275 on endothelial cells in healthy and inflamed mucosal tissues. Scand I Immunol 2006, 63:191-198.

48. Mazanet MM, Hughes CC: B7-H1 is expressed by human endothelial cells and suppresses T cell cytokine synthesis. J Immunol 2002, 169:3581-3588.

49. Makgoba MW, Sanders ME, Shaw S: The CD2-LFA-3 and LFA-1-ICAM pathways: relevance to T-cell recognition. Immunol Today 1989, 10:417-422

50. Thompson RH, Dong H, Lohse CM, Leibovich BC, Blute ML, Cheville JC, Kwon ED: PD-1 is expressed by tumor-infiltrating immune cells and is associated with poor outcome for patients with renal cell carcinoma. Clin Cancer Res 2007, 13:1757-1761.

51. Pfistershammer K, Klauser C, Pickl WF, Stockl J, Leitner J, Zlabinger G, Majdic $O$, Steinberger $P$ : No evidence for dualism in function and receptors: PD-L2/B7-DC is an inhibitory regulator of human T cell activation. Eur J Immunol 2006, 36:1104-1113.

52. Latchman Y, Wood CR, Chernova T, Chaudhary D, Borde M, Chernova I, Iwai Y, Long AJ, Brown JA, Nunes R, Greenfield EA, Bourque K, Boussiotis VA, Carter LL, Carreno BM, Malenkovich N, Nishimura H, Okazaki T, Honjo T, Sharpe AH, Freeman GJ: PD-L2 is a second ligand for PD-1 and inhibits T cell activation. Nat Immunol 2001, 2:261-268.

53. Loke P, Allison JP: PD-L1 and PD-L2 are differentially regulated by Th1 and Th2 cells. Proc Natl Acad Sci U S A 2003, 100:5336-5341.

54. Lejeune FJ, Ruegg C, Lienard D: Clinical applications of TNF-alpha in cancer. Curr Opin Immunol 1998, 10:573-580.

doi:10.1186/1479-5876-12-151

Cite this article as: Quandt et al: Synergistic effects of IL-4 and TNFa on the induction of $\mathrm{B} 7-\mathrm{H} 1$ in renal cell carcinoma cells inhibiting allogeneic T cell proliferation. Journal of Translational Medicine 2014 12:151.

\section{Submit your next manuscript to BioMed Central and take full advantage of:}

- Convenient online submission

- Thorough peer review

- No space constraints or color figure charges

- Immediate publication on acceptance

- Inclusion in PubMed, CAS, Scopus and Google Scholar

- Research which is freely available for redistribution 